\title{
LIFESTYLE AND QUALITY OF LIFE IN WORKING-AGE PEOPLE AFTER STROKE
}

\begin{abstract}
Bożena Kowalczyk ${ }^{1}$ and Bożena Zawadzka²
${ }^{1}$ Faculty of Health Sciences, Podhale State College of Applied Sciences, Nowy Targ, Poland; ${ }^{2}$ Institute of Pedagogy and Psychology, Department of Health Pedagogy, Jan Kochanowski University, Kielce, Poland

SUMMARY - Recommendations for changing one's lifestyle in the aspect of factors that increase the risk of another stroke are often included in the plan of caring for patients after stroke. The style of life is connected to the quality of life and can be formed not only by socialization but also by conscious work on its health-promoting aspect. Lifestyle is a unique configuration of everyday behavior depending mostly on the quality of life available. The aim of the research was to identify the correlation between lifestyle and quality of life in people of working age after stroke. There were 279 patients after first-ever ischemic or hemorrhagic stroke, including 131 women and 148 men. Abbreviated version of the World Health Organization Questionnaire and the Sickness Impact Profile scale were used to examine the quality of life. For assessment of the quality of life, the following indicators were created: lifestyle before stroke and lifestyle after stroke. Less healthy lifestyle before stroke resulted in lower quality of life in the psychological and environmental sphere of life in these people after stroke, especially those having suffered stroke six months to two years before. Better quality of life in people after stroke was found to be connected to a pro-health lifestyle.
\end{abstract}

Key words: Stroke; Lifestyle; Quality of life; Surveys and questionnaires; Sickness impact profile

\section{Introduction}

In recent years, the concept of lifestyle has become more important in the aspect of stroke prevention. Polish people often associate healthy lifestyle with high demands, with barriers that people have to overcome in order to lead this kind of lifestyle. This may give rise to defensive attitude and instead of changing their way of thinking and acting people might close and become unwilling to listen to arguments and take up pro-health actions. Healthy lifestyle, as understood by the people who were examined, mainly refers to two areas, physical activity and nutrition. Drugs, time management, susceptibility to stress are completive but not

Correspondence to: Bożena Kowalczyk, PhD, Podhale State College of Applied Sciences, Faculty of Health Sciences, ul. Kokoszków 71, 34-400 Nowy Targ, Małopolska, Poland

E-mail: kowalczyk-bozena@wp.pl; kowalczykbozena@hotmail. com

Received May 24, 2018, accepted January 16, 2019 key to building a healthy lifestyle ${ }^{1}$. David Mechanic discovered that the concept of lifestyle refers, among other things, to attitudes and health convictions, risky behavior, habits, healthy behavior, and preventive behavior ${ }^{2}$. Terminology of the quality of life is not complete yet, therefore there are lots of equivalent definitions and terms, and their range is often different. Besides the term of the quality of life, other terms are also used, i.e. conditions of life, standard of living, life rate, way of life, or lifestyle ${ }^{3}$. Quality of life is an interdisciplinary concept, which has many meanings. Many different researchers deal with it, to mention only social scholars such as sociologists, philosophers, economists, statisticians to whom the state of health is of minor importance, as well as scholars from the field of medicine and psychology to whom the quality of life depends on one's health. Health is understood as a positive state that can be assessed in a subjective way ${ }^{4}$. The quality of life is one of the most important Thematic 
Panels of the Poland 2020 National Foresight Program within the Research Field of Balanced Development of Poland ${ }^{5,6}$. People's health largely depends on our pro-health behavior that constitutes people's lifestyle. This behavior may result in positive or negative health results. The quality of life in the case of people having suffered stroke largely depends on the patient's general condition, as well as his lifestyle before the disease ${ }^{3}$.

Pro-health possibilities of a present-day man (length of life, technological progress in medicine, level of hygiene or discovery of antibiotics) make it possible to live a satisfying life but they may also present dangers, e.g., many diseases that are the result of prolonged life expectancy or wrong health behavior that largely reduce the quality of life ${ }^{8}$. Recommendations for changing lifestyle in the aspect of factors that increase the risk of another stroke are often given in the plan of caring for patients after stroke. Lifestyle is connected to the quality of life and it can be shaped not only by oneself. It can also be the result of conscious decisions of people who want to improve themselves and the society. Lifestyle is a unique configuration of everyday behavior, which largely depends on the quality of life available. Lower quality of life is generated by chronic diseases, and stroke is undoubtedly one of them. Chronic diseases are a source of negative emotions and this may influence the person's lifestyle ${ }^{3}$. At the same time, sick people after stroke should be educated and reminded that lifestyle is decisive for their quality of life ${ }^{9,10}$. It is also important for a sick person after stroke to maintain their health through consistent pro-health lifestyle ${ }^{11}$.

The aim of the research was to assess the connection between lifestyle and profile of the disease influence (Sickness Impact Profile) in the case of people of working age depending on the time that has elapsed since stroke.

Answers to the following questions were looked for during the research:

1. What is the connection between the lifestyle of people after stroke and the quality of their life measured by the abbreviated version World Health Organization Quality of Life Questionnaire (WHOQOL-BREF) depending on the time that has elapsed since stroke?

2. Is there a connection and what kind of connection is there between pro-health lifestyle of people after stroke and the quality of life mea- sured by the disease influence (Sickness Impact Profile) depending on the time that has passed since stroke?

\section{Material and Methods}

In the research, a method of diagnostic survey was used, along with closed questions about health behavior, set by the authors as a tool to assess lifestyle. The abridged Polish version of the WHOQOL-BREF and the Sickness Impact Profile (SIP) questionnaire on the influence of the disease were used to assess the quality of life. For analysis, a quotient of lifestyle before and after stroke was created based on eight questions from the authors' questionnaire. The questions referred to pro-health behavior before and after stroke, with five-grade answers offered. Low results implied positive action and higher results indicated more negative forms of behavior.

The research was carried out in 2015, approved by the Bioethical Commission, Regional Medical Chamber in Cracow (86/KBL/OIL/2013).

The study group consisted of 279 patients admitted to rehabilitation ward in three neighboring hospitals in Podhale, Poland. The patients had suffered ischemic stroke or hemorrhagic stroke. There were 131 women and 148 men, mean age 57.4 years. Taking into consideration the time that had elapsed since falling ill, the study subjects were divided into three groups: group 1 ( $n=103)$ 6-12 months; group $2(n=60) 13$ months to 2 years; and group $3(n=116) 2-5$ years.

Statistical analysis of the results referred to comparison of data in different groups of study subjects depending on the type of variables. In the case of quantity variables which were at least ordinal in nature it was checked if there was linear relationship between the variable and its strength and direction by use of Pearson's correlation factors (quantity variables) or Spearman's test (ordinal variables). In all tests, the level of significance was set at 0.05. Any higher levels were statistically nonsignificant.

\section{Results}

Analysis of correlation between lifestyle before stroke and quality of life assessment according to WHOQOL-BREF questionnaire yielded statistically significant differences. Analysis of correlation between 
Table 1. Correlation between lifestyle and sense of life quality and assessment of one's health in the group of study patients

\begin{tabular}{|l|l|l|l|l|l|l|}
\hline \multirow{3}{*}{ Lifestyle } & \multicolumn{3}{|c|}{ Sense of life quality (Bref1) } & \multicolumn{3}{c|}{ Assessment of one's own health (Bref2) } \\
\cline { 2 - 7 } & \multicolumn{3}{|c|}{ Time elapsed from stroke } & \multicolumn{3}{c|}{ Time elapsed from stroke } \\
\cline { 2 - 7 } & $\mathbf{6 - 1 2 \text { months }}$ & $\mathbf{1 3 - 2 4}$ months & $25-60$ months & $6-12$ months & $13-24$ months & 25-60 months \\
\hline Before stroke & $-\mathbf{0 . 2 4 0}$ & $-\mathbf{0 . 2 9 2}$ & -0.076 & $-\mathbf{0 . 2 0 7}$ & -0.208 & 0.146 \\
& $\mathrm{p}=\mathbf{0 . 0 1 5}$ & $\mathrm{p}=\mathbf{0 . 0 2 3}$ & $\mathrm{p}=0.415$ & $\mathrm{p}=\mathbf{0 . 0 3 6}$ & $\mathrm{p}=0.111$ & $\mathrm{p}=0.118$ \\
\hline After stroke & -0.171 & -0.143 & -0.087 & $\mathbf{- 0 . 2 5 4}$ & -0.092 & -0.069 \\
& $\mathrm{p}=0.085$ & $\mathrm{p}=0.276$ & $\mathrm{p}=0.351$ & $\mathrm{p}=\mathbf{0 . 0 1 0}$ & $\mathrm{p}=0.484$ & $\mathrm{p}=0.463$ \\
\hline
\end{tabular}

lifestyle before stroke and assessment of quality of life satisfaction (Bref1) showed statistically significant correlations in the groups of patients at 6-12 months $(\mathrm{p}=0.015)$ and $13-24$ months $(\mathrm{p}=0.023)$ after stroke. Negative rates of correlation between the indicator of lifestyle (with reverse coding) and one's own sense of quality of life (Bref1) in people after stroke pointed to inverse correlation. It means that the quality of life increased when the person had led a healthy lifestyle before the stroke occurred. In the group of patients examined at 25-60 months after stroke, no significant correlations were noted between the lifestyle before stroke and patient assessment of their quality of life.

Analysis of correlation between lifestyle before stroke and satisfaction with one's own health (Bref2) indicated that there were statistically significant connections in the group of patients examined at 6-12 months after stroke $(p=0.036)$. Analysis of interdependence between assessment of one's health (Bref2) at the time of examination and lifestyle after stroke showed significant dependence $(\mathrm{p}=0.010)$ only in the group of patients examined at 6-12 months after stroke. Negative rates of correlation between lifestyle indicators (with reverse coding) and one's own assessment of the quality of life pointed to inverse correlation, indicating a connection between increase in the assessment of one's health and increase of pro-health behavior before stroke. This was not the case if the lifestyle before and after stroke influenced assessment of one's health (Bref2) by patients with more than one year elapsed from stroke (Table 1).

\section{Connection of lifestyle and quality of life in its different fields}

In the case of somatic field (HEALTHCARE CENTRE1), statistically significant differences were
Table 2. Correlation between lifestyle and somatic field in the group of study patients

\begin{tabular}{|c|c|c|c|}
\hline \multirow{3}{*}{$\begin{array}{l}\text { Life- } \\
\text { style }\end{array}$} & \multicolumn{3}{|c|}{ Somatic field (HEALTHCARE CENTRE1) } \\
\hline & \multicolumn{3}{|c|}{ Time elapsed from stroke } \\
\hline & 6-12 months & 13-24 months & 25-60 months \\
\hline $\begin{array}{l}\text { Before } \\
\text { stroke }\end{array}$ & $\begin{array}{l}-0.285 \\
p=0.003\end{array}$ & $\begin{array}{l}-0.228 \\
p=0.080\end{array}$ & $\begin{array}{l}0.029 \\
p=0.760\end{array}$ \\
\hline $\begin{array}{l}\text { After } \\
\text { stroke }\end{array}$ & $\begin{array}{l}-0.240 \\
p=0.015\end{array}$ & $\begin{array}{l}-0.249 \\
p=0.055\end{array}$ & $\begin{array}{l}-0.169 \\
p=0.070\end{array}$ \\
\hline
\end{tabular}

recorded in patients with 6-12 months elapsed from stroke. The correlation between the lifestyle before stroke and HEALTHCARE CENTRE1 was statistically significant at the level of $\mathrm{p}=0.003$ and between the lifestyle after stroke and HEALTHCARE CENTRE1 at the level of $\mathrm{p}=0.015$. There were negative correlations between the fields examined. Considering reverse coding of the lifestyle indicator before and after stroke, it was noted that the less favorable the lifestyle was before stroke, the worse was the quality of life in the somatic field, and the less favorable the lifestyle was after stroke, the worse was the quality of life in the respective field. In patients with 13-24 months elapsed from stroke, the correlation was on the borderline of statistical significance $(\mathrm{p}=0.055)$, i.e. negative correlation between the lifestyle after stroke and the somatic field. It means that at the present stage of research, the existence of correlation between the variables analyzed could not be excluded (Table 2).

The use of Pearson's test proved that there was a correlation between psychological field (HEALTHCARECENTRE2) and lifestyle before stroke ( $\mathrm{p}=$ 0.000 ) in the group of patients with 6-12 months and 13-24 months elapsed from stroke $(\mathrm{p}=0.002)$. After analyzing the correlation between lifestyle after stroke 
Table 3. Correlation between lifestyle and psychological sphere in the group of study patients

\begin{tabular}{|l|l|l|l|}
\hline \multirow{2}{*}{$\begin{array}{l}\text { Life- } \\
\text { style }\end{array}$} & \multicolumn{3}{|c|}{$\begin{array}{c}\text { Psychological sphere } \\
\text { (HEALTHCARE CENTRE2) }\end{array}$} \\
\cline { 2 - 4 } & \multicolumn{3}{|c|}{ Time elapsed from stroke } \\
\cline { 2 - 4 } & $\mathbf{6 - 1 2 \text { months }}$ & $\mathbf{1 3 - 2 4}$ months & 25-60 months \\
\hline Before & $\mathbf{- 0 . 3 5 2}$ & $\mathbf{- 0 . 3 9 1}$ & -0.133 \\
stroke & $\mathbf{p}=\mathbf{0 . 0 0 0}$ & $\mathbf{p}=\mathbf{0 . 0 0 2}$ & $\mathrm{p}=0.156$ \\
\hline After & $\mathbf{- 0 . 2 4 1}$ & -0.240 & -0.150 \\
stroke & $\mathbf{p}=\mathbf{0 . 0 1 4}$ & $\mathrm{p}=0.064$ & $\mathrm{p}=0.107$ \\
\hline
\end{tabular}

Table 4. Correlation between lifestyle and social sphere in the group of study patients

\begin{tabular}{|l|l|l|l|}
\hline \multirow{2}{*}{$\begin{array}{l}\text { Life- } \\
\text { style }\end{array}$} & \multicolumn{3}{|c|}{ Social sphere (HEALTHCARE CENTRE3) } \\
\cline { 2 - 4 } & $\mathbf{3}-12$ months & $13-24$ months & 25-60 months \\
\hline Before & $\mathbf{- 0 . 3 2 5}$ & $\mathbf{- 0 . 2 6 2}$ & -0.129 \\
stroke & $\mathbf{p}=\mathbf{0 . 0 0 1}$ & $\mathbf{p}=\mathbf{0 . 0 4 3}$ & $\mathrm{p}=0.167$ \\
\hline $\begin{array}{l}\text { After } \\
\text { stroke }\end{array}$ & -0.138 & -0.210 & -0.126 \\
\hline
\end{tabular}

and HEALTHCARE CENTRE2, it turned out that there was a statistically significant correlation in the group of patients with 6-12 months elapsed from stroke. The level of significance between the variables was $p=0.014$. Results in Table 3 show that all correlations between the variables were negative. Taking into consideration reverse coding of the lifestyle factor, it is clear that correlations were inversely proportional. It means that the less favorable for health the lifestyle was before stroke, the worse was the quality of life in the psychological sphere in the group of patients with 6-24 months elapsed from stroke, and the less favorable for health the lifestyle was after stroke, the worse was the quality of life in the psychological aspect in the group of patients having suffered stroke 6-12 months before (Table 3).

The pattern of correlations between the social sphere (HEALTHCARE CENTRE3) and lifestyle before stroke also showed negative statistically significant correlations in two groups. The level of significance of correlations between variables in the group of subjects having suffered stroke 6-12 months and 1324 months before examination was $\mathrm{p}=0.001$ and $\mathrm{p}=0.043$, respectively. Reverse coding of the lifestyle
Table 5. Correlation between lifestyle and environmental sphere in the group of study patients

\begin{tabular}{|l|l|l|l|}
\hline \multirow{2}{*}{$\begin{array}{l}\text { Life- } \\
\text { style }\end{array}$} & \multicolumn{3}{|c|}{ HEALTHCARE CENTRE4 } \\
\cline { 2 - 4 } & $\mathbf{3}$ Time elapsed from stroke \\
\cline { 2 - 4 } Before & $\mathbf{- 0 . 3 4 4}$ & $\mathbf{- 0 . 2 7 1}$ & -0.179 \\
stroke & $\mathbf{p}=\mathbf{0 . 0 0 0}$ & $\mathbf{p}=\mathbf{0 . 0 3 6}$ & $\mathrm{p}=0.055$ \\
\hline After & -0.159 & $\mathbf{- 0 . 3 0 8}$ & -0.210 \\
stroke & $\mathrm{p}=0.108$ & $\mathbf{p}=\mathbf{0 . 0 1 7}$ & $\mathrm{p}=0.124$ \\
\hline
\end{tabular}

factor showed dependence, i.e. the less favorable the lifestyle was before stroke, the worse was the quality of life in social sphere in all the before-mentioned groups. There was no statistically significant correlation between social sphere and lifestyle after stroke (Table 4).

Considering the correlation between lifestyle and environmental sphere (HEALTHCARE CENTRE4), there was negative correlation between lifestyle before stroke and environmental sphere in the group of patients having suffered stroke 6-12 months $(\mathrm{p}=0.000)$ and 13-24 months ( $p=0.036)$ before, and between environmental sphere and lifestyle after stroke in the group of patients having suffered stroke 13-24 months before $(p=0.017)$. It was found that the less favorable for health the lifestyle of patients (with reverse coding) was before stroke, the worse was the quality of life in the environmental sphere in the group of patients having suffered stroke 6-12 months and 13-24 months before examination. Research results also indicated that the less favorable was the lifestyle after stroke, the worse was assessment of the life quality in the environmental sphere in the group of patients having suffered stroke 13-24 months before (Table 5).

It is interesting that there was no statistically significant correlation between the assessment of the connection of life quality and satisfaction with one's own health in all four spheres of life quality in the group of patients examined at 2-5 years after stroke (Tables 1-5).

\section{Correlation between lifestyle and profile of disease influence}

Analysis of the results on correlations between lifestyle and Sickness Influence Profile (SIP), a statistically significant correlation was found between lifestyle after stroke and physical sphere (SIP1) in the group of pa- 
Table 6. Correlation between lifestyle and physical, as well as psychosocial state according to the Sickness Impact Profile (SIP) scale

\begin{tabular}{|l|l|l|l|l|l|l|}
\hline \multirow{2}{*}{ Lifestyle } & \multicolumn{3}{|c|}{ SIP1 } & \multicolumn{3}{c|}{ SIP2 } \\
\cline { 2 - 7 } & \multicolumn{3}{|c|}{ Time elapsed from stroke } & \multicolumn{3}{c|}{ Time elapsed from stroke } \\
\cline { 2 - 7 } & $6-12$ months & $13-24$ months & $25-60$ months & $6-12$ months & $13-24$ months & $25-60$ months \\
\hline Before stroke & 0.019 & 0.010 & -0.141 & 0.057 & 0.192 & -0.013 \\
& $\mathrm{p}=0.847$ & $\mathrm{p}=0.942$ & $\mathrm{p}=0.131$ & $\mathrm{p}=0.571$ & $\mathrm{p}=0.142$ & $\mathrm{p}=0.890$ \\
\hline After stroke & $\mathbf{0 . 2 3 5}$ & $\mathbf{0 . 2 6 3}$ & 0.158 & 0.155 & 0.152 & 0.036 \\
& $\mathrm{p}=\mathbf{0 . 0 1 7}$ & $\mathrm{p}=\mathbf{0 . 0 4 3}$ & $\mathrm{p}=0.090$ & $\mathrm{p}=0.119$ & $\mathrm{p}=0.246$ & $\mathrm{p}=0.702$ \\
\hline
\end{tabular}

tients examined at 6-24 months of stroke. The level of significance of the correlation between variables was $\mathrm{p}=0.017$ and $\mathrm{p}=0.043$ in the group examined at $6-12$ months and 13-24 months after stroke, respectively. The correlation was positive in both groups.

Positive factors of correlation between the indicator of lifestyle (with reverse coding) and SIP1 with reverse interpretation of the result showed a directly proportional correlation (Table 6). It means that the less favorable for health was the lifestyle after stroke, the worse was the quality of life in the physical sphere. Analysis of the correlation between the psychosocial sphere (SIP2) and lifestyle did not yield a statistically significant correlation, thus it did not confirm the results of correlations between the psychological sphere (HEALTHCARE CENTRE2) and lifestyle (Table 3).

\section{Discussion}

Lifestyle is formed throughout the human life and influences health the most ${ }^{11,12}$. Proper information concerning the right lifestyle is an important element of health education of sick people after stroke. According to Pierzchała et al., the range of knowledge concerning the change of lifestyle in post-stroke patients should mainly include physical activity, relaxation, prevention of stress, quitting addictions, especially smoking cigarettes ${ }^{13}$. Moreover, Banecka-Majkutewicz et al. pay attention to a change of lifestyle involving moderate consumption of alcohol and avoiding smoking tobacco $^{8}$. In the research, the following was taken into consideration: physical activity, quitting addictions (smoking cigarettes and drinking alcohol) and checking blood pressure. Członkowska in her research showed that the lifestyle of people having suffered stroke was not right before falling ill. Most of them were characterized by the lack of physical activity, obesity, use of alcohol, smoking cigarettes, exposure to stress, poor diet, etc. ${ }^{14}$. Our study confirmed that the examined group of people had an unfavorable lifestyle before falling ill. Błaszczyk et al. also noted frequent lack of physical activity among the people having suffered first-ever ischemic stroke ${ }^{15}$. Hahn et al. report that sedentary lifestyle is connected to $23 \%$ of deaths due to serious chronic diseases such as stroke ${ }^{16}$. Sarzyńska-Długosz et al. think that a low percentage of people that practice physical activity as prevention and cure for chronic diseases results from disregarding these issues by doctors. Very few doctors encourage their patients to increase their daily dose of physical activity ${ }^{17}$. The study by Chiuve et al. showed that regular intense physical activity after six months of falling ill enabled more physical efforts and led to improvement of sensory and motor functions ${ }^{18}$. Banecka-Majkutewicz et al. state that if you want to decrease the risk of stroke you have to diagnose the risk factors as soon as possible and then implement the appropriate course of action, which means promoting healthy lifestyle, i.e. moderate calorie consumption, change of diet and more physical activity ${ }^{8}$. According to Opara, physical activity after stroke should be perceived as one of the most important elements of the program to decrease the risk of secondary stroke ${ }^{19}$. Błaszczyk et al. point to the importance of spreading the knowledge about stroke risk factors and proper lifestyle as prevention of secondary stroke ${ }^{15}$. Ziołkowski et al. also point to secondary prevention of brain vascular diseases. The prevention consists of detecting risk factors among the people having suffered stroke and eliminating these factors by lifestyle modification ${ }^{20}$. Simić-Panić et al. report that a large group of stroke patients have cardiac comorbidities, including arterial hypertension 
and diabetes, which belong to the modifiable risk factors for stroke ${ }^{21}$. Our and other epidemiological researches proved that lifestyle influences health much more than genetic factors or environmental factors ${ }^{8,11-18,20}$. Moreover, modifying the risk factors by healthy lifestyle is, theoretically, the most accessible but also the most difficult method of preventing cardiovascular diseases ${ }^{8}$. In 2008, Chiuve et al. defined lifestyle connected with decreasing the risk of many chronic diseases, including stroke, as follows: no cigarette smoking, body mass index $<25$, moderate physical activity for at least 30 minutes a day, moderate alcohol consumption (men 5-30 g/day and women 5-15 $\mathrm{g} /$ day), and healthy $\operatorname{diet}^{18}$. Results of the research showed differentiation of the quality of life in the study periods in different fields among the groups of post-stroke patients of working age, showing that doing prospective research by assessing the importance of improper lifestyle in forming the quality of life of people after stroke makes sense.

To sum up from the research done by many authors, as well as our own, it is clear that the level of health education of the Polish society is low, so it is justified to create and develop the existing educational programs, which increase the effectiveness of preventive actions and, in the case of post-stroke people, prevent secondary stroke ${ }^{13,15,18,22}$. Therefore, as Członkowska claims, it is important and necessary to popularize the right lifestyle as prevention of stroke ${ }^{14}$. Research results showed differentiation of the quality of life in the study time periods in different fields among the post-stroke people of working age. Interestingly, there was no statistically significant correlation between the assessed quality of life in all four spheres and satisfaction with one's own health and lifestyle in the group of patients examined at 2-5 years after stroke. The results obtained in the study showed that prospective research is necessary. The aim of the research was to assess whether improper lifestyle influenced the quality of life of people after stroke.

\section{Conclusions}

1. The quality of life differed depending on the time elapsed from stroke in different fields (measured by WHOQOL-BREF scale). Improvement of health behavior of people after stroke positively influenced assessment of the quality of life in somatic, psychological and environmental spheres.

2. Assessment of the quality of life in psychosocial sphere (SIP2) as measured by the Sickness Impact Profile scale considering the time elapsed from stroke did not confirm the results obtained in psychological sphere measured by WHOQOL-BREF scale. However, unhealthy lifestyle of post-stroke subjects was defined by low quality of life in physical sphere (SIP1).

3. Higher quality of life as an indicator of good mood of the post-stroke subjects was associated with their healthy lifestyle.

4. It is important and necessary to popularize the proper (healthy) lifestyle as a factor of preventing primary and secondary stroke.

\section{References}

1. Stanisławska J, Janikowska K, Stachowska M, Talarska D, Drozd-Gajdus E, Szewczyczak M. Assessment of women's knowledge on prevention of breast cancer and cervical cancer. Probl Hig Epidemiol. 2016;97(1):38-44.

2. Mechanic D. The rise and fall of manager care. J Health Soc Behav. 2004;45(Extra Issue):76-86.

3. Kowalczyk B, Zawadzka B. The place of residence vs. the quality of life in the case of people who suffered cerebral stroke. Studium Vilnense A. Vilnius 2018;15:135-40.

4. Melosik Z, editor. Body and Health in a Society of Consumption. Torun-Poznan; 1999.

5. Poland 2020 National Program for Modernization of Poland Foresight; Quality of Life Panel. Warsaw: PAN; 2007.

6. Papuć E. Quality of life - definitions and different types of approach. Curr Probl Psychiatry. 2011;12(2):141-5.

7. Dolata A. Influence of the family on shaping the health behaviors of children and youth. Lider. 2003;4:22-4.

8. Banecka-Majkutewicz Z, Dobkowska M, Wichowicz H. Risk factors in ischemic stroke. Ann Acad Med Gedan. 2005;35: 207-16.

9. Stroke Foundation. Manifesto of stroke 2011-2015. 2011;1-13. www.1na6.pl/index.php/download_file/view/81/107/, data dostępu 24.09.2014.

10. Rajewska-Twardowska J. Life after stroke in a holistic approach. Poznan; 2010.

11. Zysnarska M, Jarmuż L, Kara I, Adamek R, Gromadecka-Sutkiewicz M, Kłos J, Kalupa W, Maksymiuk T, Marcinkowski JT. Health behavior-related choices made by patients after myocardial infarction. Probl Hig Epidemiol. 2014;95(2):488-90.

12. Marciniak M, Królikowska A, Ślusarz R, Jabłońska R, Książkiewicz B. Nursing care for patients who had strokes. Nursing Problems. 2010;1(1):83-8. 
13. Pierzchała K, Łabuz-Roszak B, Gajewska A, Nowiński M, Zając M. Analysis of cerebrovascular risk factors in patients with stroke treated in the stroke unit. Med News. 2006;59 (1-2):44-7. PMID: 16646291

14. Członkowska A. Stroke - treatment perspectives in Poland in the light of achievements in the world. Pol Neurol Rev. 2005;1(1):1-7.

15. Błaszczyk B, Czernecki R, Prędota-Panecka H. Primary and secondary stroke prevention. Med Studies. 2008;9:71-5.

16. Hahn R, Teutsch S, Rothenberg R, Marks J. Excess deaths from nine chronic diseases in the United States 1986. JAMA. 1990;264:2654-9. http://dx.doi:10.1001/jama.1990.03450200 062032

17. Sarzyńska-Długosz I, Baranowska A, Członkowsk A. Prevalence of the metabolic syndrome in ischaemic stroke population. Neurol Neurosurg Poland. 2006;40:465-70.

18. Chiuve SE, Rexrode KM, Spiegelman D, Logroscino G, Manson JE, Rimm EB. Primary prevention of stroke by healthy lifestyle. Circulation. 2008;118(9):947-54. http://dx.doi: 10.1161/CIRCULATIONAHA.108.781062

19. Opara J. Physical activity in primary and secondary prevention after stroke. Med Tribune. 2015;10:2-4.

20. Ziołkowski M, Kubica A, Sinkiewicz W, Maciejewski W. Reducing mortality rates of ischemic heart disease in Poland - the success of therapy or healthy lifestyle? Folia Cardiol Excerpta. 2009;4(5):34-42.

21. Simić-Panić D, Bošković K, Milićević M, Rabi Žikić T, Cvjetković Bošnjak M, Tomašević-Todorović S, Jovićević M. The impact of comorbidity on rehabilitation outcome after ischemic stroke. Acta Clin Croat. 2018;57:5-15. http://dx.doi: 10.20471/acc.2018.57.01.01

22. Girzelska J, Kościołek A, Mianowana V, Dobrowolska B. Awareness of desired health behaviours as a factor conditioning educational effect by a nurse in the preparation for self-care of patients who had undergone cerebral stroke. Nurs Problems. 2010;18(4):413-9.

Sažetak

\title{
NAČIN ŽIVOTA I KVALITETA ŽIVOTA RADNO SPOSOBNIH OSOBA NAKON MOŽDANOG UDARA
}

\author{
B. Kowalczyk i B. Zawadzka
}

Preporuke za promjenu načina života u aspektu čimbenika koji povećavaju rizik od ponavljajućeg moždanog udara često su uključene u plan njege bolesnika nakon moždanog udara. Način života je strogo povezan s kvalitetom života i može se oblikovati ne samo putem socijalizacije, nego i svjesnim radom za njegovo umjeravanje u prozdravstvene navike. Cilj istraživanja bio je prepoznati odnos između načina života i kvalitete života ljudi nakon moždanog udara u produktivnoj dobi. Ispitano je 279 bolesnika nakon prvog ishemijskog i hemoragijskog moždanog udara, uključujući 131 ženu i 148 muškaraca. U istraživanju je primijenjena skraćena inačica Upitnika za kvalitetu života Svjetske zdravstvene organizacije i ljestvica Sickness Impact Profile. Za procjenu načina života utvrđeni su sljedeći pokazatelji: način života prije moždanog udara i način života nakon moždanog udara. Utvrđeno je da je kvaliteta života bila niža u psihološkim i okolišnim aspektima što je zdravstveno nepovoljniji bio način života prije moždanog udara u skupinama bolesnika koji doživjeli moždani udar prije 6-24 mjeseca. Viša razina kvalitete života ljudi nakon moždanog udara bila je povezana upravo s prozdravstvenim načinom života ovih bolesnika.

Ključne riječi: Moždani udar; Način života; Kvaliteta života; Ankete i upitnici; Profil učinka bolesti 